\title{
PEMANFAATAN BRIKET SEKAM PADI SEBAGAI PENGHASIL PANAS PADA KOMPOR GENERATOR TERMOELEKTRIK UNTUK PENERANGAN PEDAGANG KAKI LIMA
}

\author{
Suliono $^{1}$, Emin Haris ${ }^{2}$, Rachmatullah ${ }^{3}$, Abu Rizal Al Gifari ${ }^{4}$ \\ 1,2,3,4 Program Studi Teknik Mesin, Politeknik Negeri Indramayu. Jl. Lohbener Lama No.08, Lohbener, Legok, \\ Kabupaten Indramayu, Jawa Barat 45251 Tel. 0234-5746464 \\ ${ }^{1}$ Sulionolee@gmail.com, ${ }^{2}$ eminharis@gmail.com, ${ }^{3}$ rachmatullah@polindra.ac.id, ${ }^{4}$ Aburizalalgifari@gmail.com
}

\begin{abstract}
Abstrak
Pedagang Kaki Lima yang berjualan di pinggir jalan ataupun yang berjualan di taman-taman kota Indramayu mempunyai masalah penerangan lampu dan berpengaruh kepada pengunjung atau pembeli. Untuk wilayah yang dekat dengan rumah penduduk, pedagang menyalur lampu dari salah satu warga untuk menyalakan lampu dengan membayar Rp.5000,-.

Penelitian ini bertujuan untuk membantu pedagang kaki lima mengatasi masalah penerangan menggunakan energi listrik alternatif berbasis Termoelektrik Generator (TEG) jenis TEC-12706 dengan sisi menggunakan api yang dihasilkan oleh briket sekam padi sedangkan sisi dingin menggunakan kipas DC $12 \mathrm{~V}$. Penelitian ini menggunakan beberapa variasi untuk menyalakan lampu dengan efektif dan efisien, diantaranya; variasi jumlah kipas pendingin (tanpa kipas, 1 kipas dan 2 kipas), variasi rangkaian peltier (seri, paralel dan kombinasi), variasi jumlah peltier (3 peltier dan 6 peltier).

Hasil pengujian pada Termoelektrik Generator (TEG) dihasilkan perbedaan temprature paling tinggi menggunakan 1 kipas dengan $131.4^{\circ} \mathrm{C}$, rangkaian dengan 3 peltier yang menghasilkan tegangan, arus dan daya yang paling tinggi menggunakan rangkaian seri dengan $6.84 \mathrm{~V}, 0.28 \mathrm{~A}$, dan $1.92 \mathrm{~W}$, dan yang mampu menyalakan lampu DC $12 \mathrm{~V} 5$ Watt menggunakan 6 peltier dengan menghasilkan 13.5V, 0.55A, dan 7.425W. Sehingga dengan enam peltier dapat menyalakan satu kipas dan satu lampu DC 5 watt. Sehingga pedagang dapat menyalakan lampu dari kompornya
\end{abstract}

Kata Kunci : Briket Sekam padi, Generator Termoelektrik, listrik, Pedagang Kaki Lima,

\section{PENDAHULUAN}

Wilayah indramayu merupakan daerah pesisir utara pulau jawa khususnya jawa bagian barat. Indramayu sendiri adalah daerah penghasil gabah nasional yang daerahnya $90 \%$ lahannya adalah persawahan. Dari hasil sawah itu mayoritas adalah padi. Dalam setahun panen padi 3 kali dalam setahun yang dihasilkan diindramayu. Sehingga jumlah biomassa sekam padi sangat melimpah dan semakin menggunung. Untuk mengurangi penumpukan sekam padi yang semakin banyak maka dibuat briket sekam padi yang dapat dipakai untuk keperluan lain. salah satunya adalah untuk memasak pada kompor yang dapat diaplikasikan pada pedagang kaki lima. Penelitian yang dilakukan Siahaan S. et al [1] Tentang Penentuan Kondisi Optimum Suhu Dan Waktu Karbonisasi Pada Pembuatan Arang Dari Sekam Padi yang memvariasikan waktu 30, 60, 90 menit. Hasil pada kondisi optimum karbonisasi untuk sekam padi, yaitu pada suhu $400{ }^{\circ} \mathrm{C}$ selama 120 menit dengan kadar karbon terikat 41,3\%, kadar air 6,1\%, kadar abu 32,6 \% dan kadar zat mudah menguap 20,5\%. Pada penelitian berikutnya yang dilakukan Qistina I. et al [2] yang meneliti tentang briket sekam padi

$$
\text { Teknologi Tepat Guna }
$$


dan tempurung kelapa. Hasilnya menunjukkan penurunan kadar air bahan baku briket sekam padi dan tempurung kelapa membutuhkan energi masing-masing $8.54 \%$ dan $4.97 \%$ dari proses karbonisasi murni yang menghasilkan semi arang. Penelitian mengenai potensi biomassa sekam padi untuk pembangkit pembangkit listrik belum lama ini telah diteliti oleh Pujotoro, I [3], dari hasil penelitian menunjukkan gasifikasi Biomassa sekam padi merupakan salah satu harapan untuk pemenuhan energi listrik khususnya di pedesaan serta proses konversi energi sekam padi melalui teknologi gasifikasi menjadi energi listrik dicapai sebesar $30 \%$ maka energi listrik yang dapat dihasilkan adalah sebesar 49,5 MWh. Di negara maju, energi biomassa popular digunakan sebagai sumber bahan bakar untuk pembangkit listrik. Energi biomassa juga bisa diterapkan pad kompor untuk membangkitkan energi listrik melalui Efek Seebeck. Penelitian yang dilakukan Sugiyanto, et al [4] mengenai Pemanfaatan kompor gas elpiji untuk membangkitan energi listrik menggunakan generator termoelektrik dengan membandingkan 2 tipe yaitu TEG 127-40A dan TEG 126-40A. Hasil dari pengujiannya menunjukkan TEG 126-40A lebih baik dari TEG 127-40A dengan $4.17 \mathrm{~V}$ dan 0.48 A. sedangkan TEG 127-40A menghasilkan TEG 127-40A. Sehingga generator termoelektrik sangat cocok untuk para Pedagang kaki lima atau pedagang yang berjualan di malam hari yang berada dipinggir jalan kota Indramayu. Karena para pedagang sering mempunyai masalah pada penerangan lampu untuk berjualan dimalam hari. sedangkan masyarakat yang ingin berjualan masih belum mengetahui cara mendapatkan listrik. Jadi untuk mendapatkan listrik pedagang harus bertanya kepada warga sekitar tempat berdagang untuk menyalur lampu. Jika warga sekitar menolak memberikannya maka pedagang harus mencari tempat lain yang ada penerangan jalan atau warga menyalurkan listrik untuk pedagang tersebut. Padahal tempat yang pedagang inginkan adalah tempat yang ramai dan selalu dikunjungi warga sekitar. Adapun jika seorang pedagang yang ingin menyalur listrik dari penduduk sekitar, maka harus membayar Rp 5.000 - 10.000 perhari, itupun hanya sampau jam 12 malam saja para pedagang menjual dagangannya. Hal inilah yang melatarbelakangi untuk menciptakan sebuah alat yang dibutuhkan oleh masyarakat yang ingin berwirausaha dimalam hari. Muflih Wijaya, et al [5] Dalam penelitiannya Pemanfaatan Energi Panas dari Wajan Penggorengan Untuk Lampu Penerangan Warung Padagang Kaki Lima. dari hasil eksperimennya yaitu memanfaatkan panas dari wajan untuk mengubahnya menjadi energi listrik. Maka biaya yang dikeluarkan lebih hemat jika dibandingken menggunakan genset. Prinsip kerja dari generator termoelektrik yaitu:

\section{A. Generator Termoelektrik}

. Pembangkit thermoelektrik (TEG) [6] adalah suatu pembangkit listrik yang didasarkan pada efek seebect,yang pertama kali ditemukan pada tahun 1821 oleh Thomas Johan Seebect, ia menghubungkan tembaga dan besi dalam sebuah rangkaian. Diantara kedua logam tersebut diletakkan jarum kompas. Ketika sisi logam tersebut dipanaskan jarum tersebut ternyata bergerak.

\section{B. Efek Seebeck}

Efek Seebeck merupakan fenomena yang mengubah perbedaan temperatur panas dan dingin menjadi energi listrik. Jika ada dua bahan yang berbeda yang kemudian kedua ujungnya disambungkan satu sama lain maka akan terjadi dua sambungan dalam satu loop. Jika terjadi perbedaan suhu maka akan muncul arus listrik. Prinsip ini lah yang digunakan termoelektrik sebagai generator (pembangkit listrik) [7]. Prinsip kerja pada kompor penghasil listrik ini adalah peltier dengan tipe TEC1-12706 akan dipanaskan oleh api dari briket dan didinginkan dengan kipas / fan sehingga akan ada perbedaan temprature dan akan menghasilkan listrik arus DC yang dinamakan efek seebeck. Berikut adalah gambar kerja seebeck 


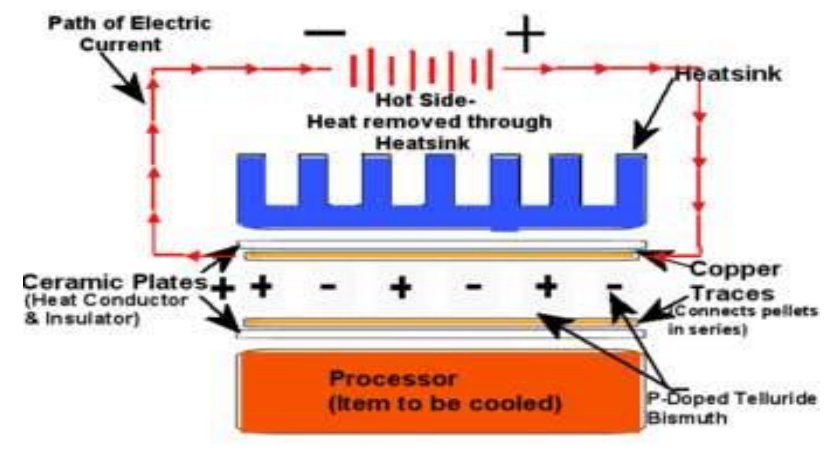

Gambar 1. Efek seebeck

Koefisien Seebeck disimbolkan dengan huruf dengan maka koefisien Seebeck dituliskan:

$$
\alpha=\frac{V}{\Delta T}
$$

$\alpha=$ Koefisien seebeck Volt per Menit $(\mathrm{V} / \mathrm{m})$

$V=$ Tegangan dalam Volt $(\mathrm{V})$

$\Delta T=$ Perbedaan Temprature dalam Kelvin $(\mathrm{K})$

Adapun besarnya kalor yang diserap disimbolkan dengan $\mathrm{q}$, dengan satuan internasional (W)

$$
\mathrm{q}=\alpha . \mathrm{I} . \Delta T
$$

$\mathrm{q}=$ besar Kalor yang diserap dalam $(\mathrm{W})$

$\mathrm{I}=$ Arus listrik dalam Ampere (A)

$\Delta T=$ Perbedaan Temprature dalam Kelvin $(\mathrm{K})$

\section{Tegangan Listrik}

Tegangan adalah perbedaan potensi listrik antara dua titik dalam rangkaian listrik, dinyatakan dalam satuan volt. Besaran ini mengukur energi potensial sebuah medan listrik untuk menyebabkan aliran listrik dalam sebuah konduktor listrik. Terdapat dua cara memandang beda potensial [8], yaitu :

1. Tegangan turun/voltage drop Jika dipandang dari potensial lebih tinggi ke potensial lebih rendah.

2. Tegangan naik/voltage rise Jika dipandang dari potensial lebih rendah ke potensial lebih tinggi.

Simbol tegangan adalah V (voltage). Sedangkan Satuan Internasional untuk tegangan adalah Volt. Persamaan matematik untuk tegangan adalah:

$$
\mathrm{V}=\mathrm{I} \cdot \mathrm{R}
$$

$\mathrm{V}=$ Tegangan dalam Volt $(\mathrm{V})$

$\mathrm{R}=$ Resistansi dalam $\operatorname{Ohm}(\Omega)$

$\mathrm{I}=$ Arus dalam Ampere $(\mathrm{A})$

\section{Arus Listrik}

Arus listrik merupakan banyaknya muatan listrik yang mengalir tiap satuan waktu. Muatan listrik bisa mengalir melalui kabel atau penghantar listrik lainnya. Arus listrik dapat terjadi karena adanya aliran elektron dimana tiap electron mempunyai muatan yang besarnya sama. Arus listrik dapat dibedakan menjadi 2, yaitu :

1. Arus searah (Direct Current / DC), yaitu arus yang mempunyai nilai tetap atau konstan terhadap satuan waktu.

2. Arus bolak-balik (Alternating Current / AC), yaitu arus yang mempunyai nilai berubah terhadap satuan waktu dengan karakteristik akan selalu berulang untuk periode waktu tertentu

Simbol arus adalah I, sedangkan satuannya arus adalah Ampere. Dengan persamaan:

$$
\mathrm{I}=\mathrm{V} / \mathrm{R}
$$

$\mathrm{I}=$ Arus listrik dalam Ampere (A)

$\mathrm{V}=$ Tegangan dalam Volt $(\mathrm{V})$

$\mathrm{R}=$ Resistansi dalam $\operatorname{Ohm}(\Omega)$

\section{E. Daya Listrik}

Daya listrik yang didefinisikan sebagai laju hantaran energi listrik dalam satu rangkaian listrik.

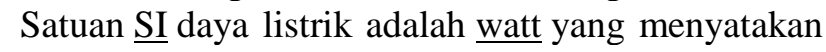
banyaknya tenaga listrik yang mengalir per satuan waktu (joule/detik). Simbol arus adalah P, sedangkan satuannya daya adalah Watt [9]. Dengan persamaan:

$$
\mathrm{P}=\mathrm{V} . \mathrm{I}
$$

$\mathrm{P}=$ Daya listrik dalam Watt $(\mathrm{w})$

$\mathrm{V}=$ Tegangan listrik dalam Volt $(\mathrm{V})$

$\mathrm{I}=$ Arus listik dalam Ampere (A)

Hukum Joule dapat digabungkan dengan hukum Ohm untuk menghasilkan dua persamaan tambahan:

$$
\mathrm{P}=I^{2} . \mathrm{R}=\frac{V^{2}}{R}
$$

$\mathrm{P}=$ Daya listrik dalam Watt $(\mathrm{w})$

$\mathrm{V}=$ Tegangan listrik dalam Volt $(\mathrm{V})$

$\mathrm{I}=$ Arus listik dalam Ampere (A)

$\mathrm{R}=$ Hambatan dalam $\mathrm{Ohm}(\Omega)$

\section{METODE}

Kompor tungku adalah kompor yang digunakan untuk memasak dengan menggunakan bahan bakar briket sekam padi. Tungku kompor dibuat dengan plat $1 \mathrm{~mm}$, dirancang dengan ukuran yang sudah ditentukan, Pada bagian dalam dilapisi

$$
\text { Teknologi Tepat Guna }
$$


oleh semen tahan panas sehingga dapat mencegah api berhubungan langsung dengan plat sehingga plat tidak mudah korosi selain itu agar kalor tidak tidak menyebar. Lalu dipasangkan 2 heatsink yang ditengah tengahnya telah dipasangkan peltier. Gambar dibawah ini adalah alat pengujian yang dipakai untuk pengambilan data.

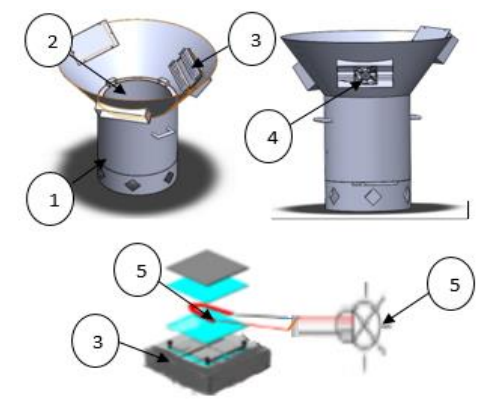

Gambar 2. Tungku kompor biomassa

Keterangan :

1. Tungku kompor

2. Ruang pembakaran briket

3. Heatsink

4. Kipas / Fan

5. Peltier TEC1-12706

6. Lampu LED

Bahan yang digunakan pada pengujian tungku kompor briket adalah sebagai berikut :

Tabel 1. Bahan Yang Digunakan

\begin{tabular}{|c|l|c|c|}
\hline No. & Nama Bahan & Jumlah & Satuan \\
\hline 1. & Plat 1mm & 1 & $\mathrm{~L}$ \\
\hline 2. & Semen tahan api & 1 & Sak \\
\hline 3. & $\begin{array}{l}\text { Peltier } \\
\text { TEC1-12706 }\end{array}$ & 6 & Buah \\
\hline 4. & Briket sekam padi & 20 & $\mathrm{Kg}$ \\
\hline 5. & Kipas / fan & 2 & Buah \\
\hline 6. & Heatshink & 2 & Buah \\
\hline 7. & Lampu LED DC & 3 & Buah \\
\hline
\end{tabular}

\section{F. Tempat Pengujian}

Tempat Pengujian Lokasi pengujian kompor penghasil listrik dilakukan di outdoor lebih tepatnya halaman workshop teknik mesin Polindra karena kompor penghasil listrik ini diperuntukan pedagang kaki lima sehingga ketika dipakai oleh pedagang kaki lima data yang diambil tidak begitu jauh perbedaanya. Dan diadakanya pengujian untuk mengetahui luaran yang terbesar dari termoelektrik dengan meninjau tegangan, arus dan daya yang dihasilkan termoelektrik generator sehingga mendapatkan output bisa menyalakan lampu untuk penerangan PKL.

\section{G. Pengambilan Data}

Pengambilan data dilakukan setelah kompor penghasil listrik selesai dibuat dan komponen telah tersedia semua, pengambilan data sebanyak 5 kali pengambilan dengan kondisi api sudah menyebar / konstan. Adapun aspek yang diambil datanya adalah sebagai berikut :

1. Pengambilan data perbedaan temprature dengan menggunakan thermocouple pada tiga variasi kipas / fan yaitu tanpa kipas, 1 kipas dan 2 kipas, pengambilan data setelah api konstan dan setiap 2 menit sekali sampai 5 kali percobaan.

2. Pengambilan data tegangan dan arus yang dengan menggunakan multimeter pada variasi rangkaian peltier yaitu seri, paralel dan kombinasi seri paralel, pengambilan data menggunakan 3 peltier dilakukan setelah api konstan dan setiap 2 menit sekali sampai 5 kali percobaan.

3. Pengambilan data tegangan dan arus dengan menggunakan multimeter pada 6 peltier untuk bisa menyalakan lampu $12 \mathrm{~V} 5 \mathrm{~W}$, dilakukan setelah api konstan dan setiap 2 menit sekali sampai 5 kali percobaan.

Proses dilakukan secara berurutan dan dilakukan sehingga menghasilkan listrik dengan tegangan minimal $12 \mathrm{~V}$ sehingga dapat menyalakan 1 kipas dan lampu.

\section{H. Analisis}

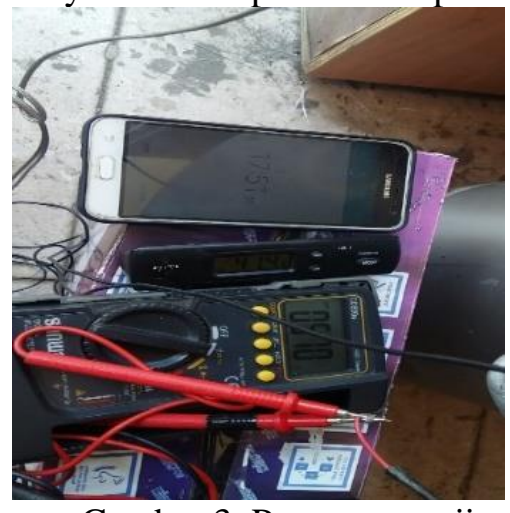

Gambar 3. Proses pengujian

Analisis dilakukan setelah semua data terkumpul, analisis dilakukan untuk mengetahui perbandingan data-data yang telah terkumpul dan memilih mana yang lebih efektif dan efisien. 
Adapun beberapa analisis yang dilakukan adalah sebabagi berikut :

1. Menganalisis variasi kipas mana yang paling besar beda temprature-nya, sehingga akan menghasilkan tegangan dan arus yang besar juga.

2. Menganalisis variasi rangkaian peltier yang lebih besar menghasilkan tegangan dan arus listriknya yang akan dipilih pada pengujian selanjutnya sehingga tidak perlu menggunakan lebih banayak penggunaan peltier.

3. Menganalisis untuk langsung menggunakan 6 peltier, dan menganalisis tegangan dan arus yang dihasilkan dapat menyalakan berapa buah lampu.

\section{HASIL DAN PEMBAHASAN}

\section{Hasil Pengujian Variasi Kipas}

Dari pengujian tungku yang menggunakan sekam padi sebagai penghasil panas dapat dilihat perbedaan pengukuran Themprature paling tinggi adalah menggunakan 1 kipas dengan nilai $132^{\circ} \mathrm{C}$ sehingga penelitian yang akan digunakan 1 kipas. Ada beberapa faktor yang membuat suhu tidak konstan yaitu adanya pengaruh angin dan api pada briket tidak stabil. Gambar dibawah ini menunjukkan grafik pada perbedaan temperature dengan 3 variasi kipas yaitu:

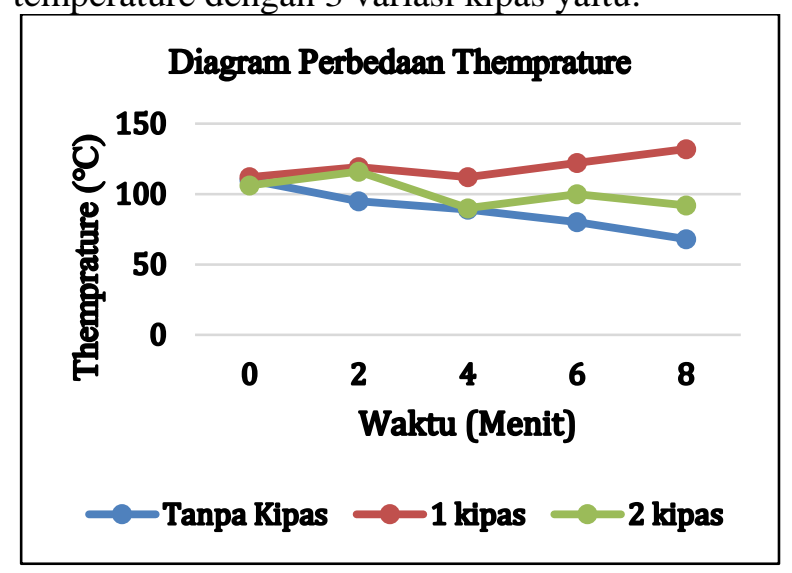

Gambar 4. Diagram perbedaan temperature

\section{Hasil Pengujian Variasi Rangkaian Peltier}

Tegangan dan arus listrik yang dihasilkan dari beberapa variasi rangkaian yaitu seri dan paralel dan kombinasi. Dari data diatas ternyata arus dari rangkaian seri yang diperoleh lebih besar. Dari data yang ditunjukkan pada grafik di bawah ini rangkaian seri lebih baik bila dibandingkan dengan rangkaian yang lain dengan menghasilkan $6,846 \mathrm{~V}$ dan arus 0,28A. Berikut gambar grafik yang menunjukkan perbedaan rangkaian seri, paralel dan kobinasi.

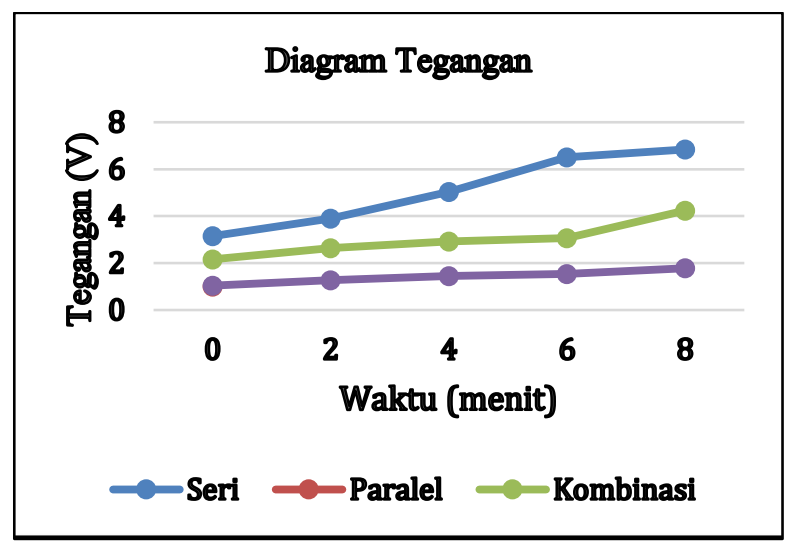

Gambar 5. Diagram Tegangan

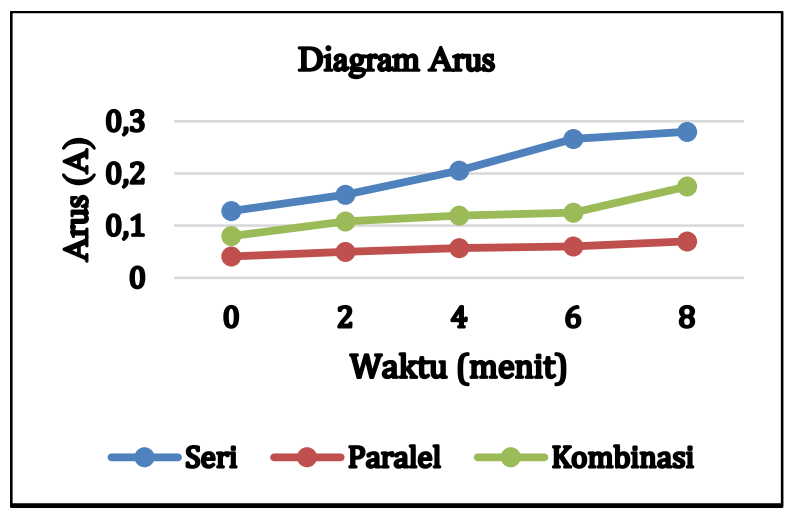

Gambar 6. Diagram tegangan

Gambar diatas menunjukkan bahwa pengukuran perbandingan arus dari rangkaian seri, paralel dan kombinasi. grafik diatas menunjukkan rangkaian seri lebih baik dari rangkaian yang lain. Rangkaian seri bisa lebih tinggi dengan menghasilkan arus diatas 0,2 dan hampir mendekati 0.3 sehingga bila digunakan untuk lampu bisa menghidupka sebesar 5 watt. Karena rangkaian seri hanya menggabungkan komponen dari masing masing peltier sehingga arus yang keluar bisa lebih tinggi.

\section{Hasil Pengujian 6 Peltier Seri}

Tabel dibawah ini menunjukkan hasil pengukuran temperatur, tegangan dan arus pada pengujian yang menggunakan kompor tungku

$$
\text { Teknologi Tepat Guna }
$$


masak dengan menggunakan 6 peltier. dari hasil pengujian didapat dilihat pada tabel berikut ini:

Tabel 2. Enam peltier rangkaian Seri

\begin{tabular}{|c|c|c|c|}
\hline Menit & $\begin{array}{c}\Delta \mathrm{T} \\
\left({ }^{\circ} \mathrm{C}\right)\end{array}$ & $\begin{array}{c}\text { Tegangan } \\
(\mathrm{V})\end{array}$ & $\begin{array}{c}\text { Arus } \\
(\mathrm{A})\end{array}$ \\
\hline $0 /$ Konstan & 36 & 10,8 & 0.44 \\
\hline 2 & 37 & 11,1 & 0.45 \\
\hline 4 & 40 & 12 & 0.49 \\
\hline 6 & 41 & 12,3 & 0.50 \\
\hline 8 & 45 & 13,5 & 0.55 \\
\hline
\end{tabular}

Setelah melakukan pengujian dengan menggunakan 6 peltier mendapatkan tegangan paling tinggi adalah $13,5 \mathrm{~V}$ dan arus tertinggi $0,55 \mathrm{~A}$ dan dapat menyalakan lampu pada menit ke-6 dari api konstan.

\section{KESIMPULAN}

Berdasarkan dari hasil penelitian yang telah dilakukan menghasilkan luaran tertinggi adalah $13 \mathrm{~V}, 0.55 \mathrm{~A}, 24.54 \mathrm{Ohm}$, dan 7.425 Watt. dengan menggunakan 6 buah peltier yang diserikan yang mampu menyalakan 1 lampu dan 1 kipas pendingin. Dengan demikian kompor ini bisa digunakan oleh pedagang kaki lima sebagai alat untuk memasak sekaligus untuk penerangan lampu pada saat berjualan dan dapat mengurangi biaya sewa listrik dan pembelian gas elpiji.

\section{REFERENSI}

Siahaan, S. et al. (2013). Penentuan Kondisi Optimum Suhu Dan Waktu Karbonisasi Pada Pembuatan Arang Dari Sekam Padi. Jurnal Teknik Kimia USU, Vol. 2, No. 1

Qistina, Idzni et al. (2016). Kajian Kualitas Briket Biomassa dari Sekam Padi dan Tempurung Kelapa. Jurnal Kimia VALENSI: Jurnal Penelitian dan Pengembangan Ilmu Kimia, 2(2). 136-142.
Pujotomo, I. (2017). Potensi Pemanfaatan Biomassa Sekam Padi Untuk Pembangkit Listrik Melalui Teknologi Gasifikasi

Sugiyanto, Siswantoro. S. (2014). Pemanfaatan Panas Pada Kompor Gas LPG Untuk Pembangkitan Energi Listrik Menggunakan Generator Termoelektrik. Jurnal Teknologi, Volume 7 Nomor 2. 100-105.

Wijaya, M., \& Prihartanto, E. (2010). Pemanfaatan Energi Panas dari Wajan Penggorengan Untuk Lampu Penerangan Warung Padagang Kaki Lima. Jurnal Riset Industri Vol. IV No 2: 29-32.

Cekdin, C et al. (2018). Pengaruh Temperatur Terhadap Resistansi Thermoelektric Generator Tipe SP 1848-27145 Modul 5 Susunan Seri Ketika Dipanaskan. Jurnal Surya Energy Vol. 3 No. 1

Satria, M. Gilang. (2015). Rancang Bangun Energi Terbarukan Dengan Memanfaatkan Energi Panas Dari Kondensor Mesin Pendingin. Jurnal Ilmiah TEKNOBIZ Vol. 5 No.3

Julianto, T.et al. (2016). Pemanfaatan Perbedaan Temperatur Pada Main Engine Cooling System Sebagai Energi Alternatif Untuk Pembangkit Listrik Di Kapal. JURNAL TEKNIK Vol. 5., N0. 2 ISSN: 2337-3539.

Gitrio, Agung et al. (2015). Karakteristik Pembangkitan Thermoelektric Menggunakan Enam Buah Modul Peltier Secara Seri dan Paralel. Undergraduated thesis Universitas Bengkulu. 